\title{
JUURNAL.RU
}

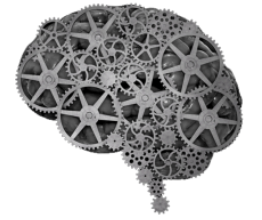

COMPANY GROUP "INTELLEKT"

Коржинов Т.Е., Гоц И.Ю. СГТУ имени Гагарина Ю.А. Саратов, Россия

Научные руководители: Барабанов С.Н., Пичхидзе С.Я.

doi: 10.18411/1j2016-4-42

\section{Исследование процесса утилизации продуктов органического происхождения методом высокотемпературного пиролиза}

Высоко углеродсодержащий материал - это уникальный материал, который был в полной мере оценен лишь в прошлом веке. Полученный продукт методом высокотемпературного пиролиза можно использовать, так как и его близкий по составу и свойствам материал - древесный уголь с содержанием углерода до $90 \%$ в металлургической промышленности, производстве активированных углей, в сельском хозяйстве, медицине строительстве, для отопления помещений и приготовления пищи [1].

Цель работы: исследовать возможность процесса утилизации продуктов органического происхождения (подсолнечная лузга) методом пиролиза.

В ходе работы использовались следующие установки: производственная установка для пиролиза, спектрофлюориметр флюорат-02-2М.

В результате проведения исследований на пиролитической установке были получены оптимальные режимы производства высоко углеродсодержащего продукта, элементный химический состав которых установлен с помощью флюориметрического метода [2-3].

Согласно результатам табл.1-3 наибольший процент углерода получен при температуре $420{ }^{\circ} \mathrm{C}$.

Выводы: на основании установленного химического состава в результате 
проведенных исследований выбран оптимальный режим пиролиза сельскохозяйственных отходов. При температуре $420{ }^{0} \mathrm{C}$ и загрузочной массе сырья в 5 кг в течение 20 минут получен углеродсодержащий продукт с количеством 91...94\% углерода в составе.

Таблица 1

Режим № 1

Температура обработки $-420^{\circ} \mathrm{C}$

\begin{tabular}{|l|l|l|l|l|l|l|l|l|}
\hline Спектр & $\mathrm{C}$ & $\mathrm{O}$ & $\mathrm{Mg}$ & $\mathrm{Si}$ & $\mathrm{P}$ & $\mathrm{S}$ & $\mathrm{K}$ & $\mathrm{Ca}$ \\
\hline 1 & 93.26 & 6.34 & 0.06 & 0.02 & & & 0.32 & \\
\hline 2 & 93.68 & 5.89 & 0.06 & 0.01 & & & 0.36 & \\
\hline 3 & 91.43 & 8.14 & & 0.00 & & & 0.34 & \\
\hline 4 & 94.08 & 5.43 & & 0.01 & & & 0.49 & \\
\hline
\end{tabular}

Таблицฺа 2

Режим № 2

Температура обработки $-450^{\circ} \mathrm{C}$

\begin{tabular}{|l|l|l|l|l|l|l|l|l|}
\hline Спектр & $\mathrm{C}$ & $\mathrm{O}$ & $\mathrm{Mg}$ & $\mathrm{Si}$ & $\mathrm{P}$ & $\mathrm{S}$ & $\mathrm{K}$ & $\mathrm{Ca}$ \\
\hline 1 & 85.72 & 12.30 & 0.50 & & 0.08 & 0.06 & 0.93 & 0.39 \\
\hline 2 & 76.31 & 15.97 & 0.71 & 0.01 & 0.19 & 0.33 & 3.34 & 3.14 \\
\hline 3 & 90.13 & 8.59 & 0.21 & 0.02 & & & 0.93 & 0.12 \\
\hline 4 & 85.32 & 12.83 & 0.39 & & 0.11 & 0.09 & 0.85 & 0.41 \\
\hline
\end{tabular}

Режим № 3

Таблица 3

Температура обработки $-480{ }^{\circ} \mathrm{C}$

\begin{tabular}{|l|l|l|l|l|l|l|l|l|l|l|}
\hline Спектр & $\mathrm{C}$ & $\mathrm{O}$ & $\mathrm{Mg}$ & $\mathrm{Si}$ & $\mathrm{P}$ & $\mathrm{S}$ & $\mathrm{Cl}$ & $\mathrm{K}$ & $\mathrm{Ca}$ & $\mathrm{Zn}$ \\
\hline 1 & 75.47 & 19.71 & 0.59 & 0.13 & 0.15 & 0.40 & 0.46 & 1.98 & 0.74 & 0.38 \\
\hline 2 & 83.47 & 14.54 & 0.27 & & & & 0.09 & 1.31 & 0.32 & \\
\hline 3 & 76.11 & 19.18 & 0.74 & & & 0.43 & 0.43 & 1.86 & 0.84 & 0.38 \\
\hline 4 & 78.00 & 16.13 & 0.85 & & & 0.38 & 0.54 & 2.68 & 1.35 & 0.06 \\
\hline
\end{tabular}




\section{Литература:}

1. Способ получения и сорбционные свойства лигнифицированной шелухи подсолнечника / Л. А. Купчик, С. А. Торгонская, А. А. Николайчук / Науч.техн. журн. Энерготехнологии и ресурсосбережение, № 4, 2011. - С. 58-62.

2. Ефремова С.В., Сухарников Ю.И., Савченко А.М. Установка для термической переработки рисовой шелухи / Современная лаборатория, № 1, 2010. - C. 41-42.

3. Ефремова С.В., Королев Ю.М., Сухарников Ю.И. Рентгенографическая характеристика кремнеуглеродных нанокомпозитов из рисовой шелухи и ее производных / ДАН, № 1, Т.419, 2008. - С. 77-80. 